\title{
Global Journal of Medicinal Plant Research
}

2017. 5(1): 1-8

ISSN: 2074-0883

DOI: 10.22587/gjmpr.2017.5.1.1

Journal home page: http://www.aensiweb.com/GJMPR/

RESARCH ARTICLE

\section{Herbal Remedies Used in the Treatment of Scorpion Stings in Saudi Arabia}

\author{
${ }^{1}$ Amal, M. Fakhry, ${ }^{2}$ Masarrat, M. A. Migahid and ${ }^{3}$ Hanan, K. Anazi \\ ${ }^{1}$ Botany Department, Faculty of Science, Alexandria University, Egypt. \\ ${ }^{2}$ Biological and Geological Sciences Department, Faculty of Education, Alexandria University, Egypt. \\ ${ }^{3}$ Biology Department, Faculty of Science, Tabuk University, Saudi Arabia.
}

\begin{abstract}
Background: Research on use of traditional medicines obtained from plants has received considerable interest. Medicinal plants are an important element of indigenous medical systems in Saudi Arabia and elsewhere. The population in the areas under the present study use plant products as a therapy to considerable extent although the modern medical facilities are available. Objective: The present study is conducted for scientific identification and documentation of herbal medicine knowledge and experience of tribal communities in Saudi Arabia. An ethno-botanical survey is conducted on the plants used for treatment of scorpion stings by tribal communities in two districts of Saudi Arabia namely, Tabuk in northwestern region and Jeddah in southwestern region. Results: From the survey conducted in the present study, twelve plant species belonging to eleven families of angiospermae are used for treatment of scorpion stings in the study areas. Six plant species are recorded in Tabuk and other six species in Jeddah. Alliaceae family is common in the two studied regions. Astragalus spinosus(Fabaceae) and Heliotropium bacciferum(Boraginaceae)are the most commonly used plant species for treatment of scorpion stings in Tabuk, while Allium sativum (Alliaceae) and Linum usitatissimum (Linaceae) in Jeddah. Wild plant species are commonly used in the northwestern region of Saudi Arabia, where five out of six species (about 83\%) are wild desert plants. Cultivated and imported plant species are the most commonly used (about 67\%) in the southwestern region. Generally, leaves, bulbs and seeds are the commonest parts of plants used, while decoctions, infusions, pulverization and grinding are the main methods of preparations. Conclusion: Herbal medicines are effectively used for the treatment of patients with scorpion envenomation. This type of medication is free from side effects as observed with chemical antidotes or anti-venom therapy. Further studies are required to identify the active ingredients of these plant species for improving their therapeutic potential as traditional medicines.
\end{abstract}

Key words: Ethno botany; Scorpion Stings; Medicinal plants; Saudi Arabia.

Address for Correspondence:

Amal, M. Fakhry, Botany Department, Faculty of Science, Alexandria University, Egypt.

E-mail: amalfakhry@live.com

Received date: 12 June 2017, Accepted date: 28 December. 2017, Online date: 31 December. 2017

\section{INTRODUCTION}

Scorpions are widely distributed throughout the world and pose serious health hazard due to their poisonous venoms (Al-Asmari et al., 2015 and Al-Asmari et al., 2016). Venom is a heterogeneous mixture of various neurotoxins, cardio toxins, nephron toxins and haemolytic toxins that exert acute toxicological effects in humans (Bawaskar and Bawaskar, 2012). The degree of envenomation is associated with several factors including scorpion species, venom lethality, dose of venom injected at the time of sting and the victim's physiological response to venom (Karnad, 2009).

Open Access Journal

Published BY AENSI Publication

(C) 2017 AENSI Publisher All rights reserved

This work is licensed under the Creative Commons Attribution International License (CC BY) http://creativecommons.org/licenses/by/4.0/

(C) (i) Open Access

To Cite This Article: Amal, M. Fakhry, Masarrat, M. A. Migahid and Hanan, K. Anazi. Herbal Remedies Used in the Treatment of Scorpion Stings in Saudi Arabia. Glob. J. Med. Plant Res, 5(1): 1-8, 2017 
Scorpion stings are a major public health problem in many countries, including deserts of Saudi Arabia. Patients often get life threatening complications. Envenomation due to scorpion sting results in various clinical manifestations. They range from mild local pain to diffuse intolerable pain of whole limb and body to systemic manifestation involving almost all systems, predominantly cardiovascular and may sometimes lead to death (Devarbhavi and Murthy, 2013).

Ethnobotany is a multidisciplinary science, defined as the interaction between plants and people (Yogamaya et al., 2011), and deals the use of herbal sources in traditional medicine, which was in practice for more than5000 years (Abu-Rabia, 2011). It is important to note that more than $25 \%$ of drugs are of plant origin and more than 100 active compounds and synthetically produced drug analogues come from natural precursors (Shinwari, 2010). Ethno pharmacological research is considered crucial in the development and discovery of new drugs from natural sources (Fransworth and Soejarto,1985). Many of the global population still depend upon the herbal drugs for their health care. Various cultural traditions are associated with use of wild plants as medicinal herbs. This medico-lore is passed over generations traditionally all over the world. Various medicinal plants are being used as folk medicines in the treatment of scorpion sting.

Two thirds of the Arabian Peninsula is occupied by the Kingdom of Saudi Arabia, covering a wide range of habitats with great biodiversity and synergistic framework of associated ecosystems (Ghazanfar,1994). The deserts and mountains of Saudi Arabia are covered with more than 2500 plant species most of which are noted for their uses as medicinal herbs. Although there are many reports on barcoding of medicinal and wild plants of Saudi Arabia (Bafeel et al., 2011, Bafeel et al., 2012a and Bafeel et al., 2012b), a comprehensive survey of the use of medicinal plants for the treatment of scorpion sting victims is lacking. The use of different parts of several medicinal plants in Saudi Arabia to cure specific ailments has been practiced since ancient times. Despite the long history of treating scorpion stings in Saudi Arabia regions using herbal remedies, the knowledge and experience of these herbalists have not been scientifically documented. The objective of the current study is to document the medicinal plants in Tabuk and Jeddah districts that are used for treatment of patients of scorpion stings as an alternative medicine.

\section{MATERIALS AND METHODS}

The survey was carried out in different areas for each selected district in Saudi Arabia namely, Tabuk and Jeddah throughout October to December 2015, which located along the western coast of the country, facing Egypt and Sudan across the Red Sea (Figure 1).

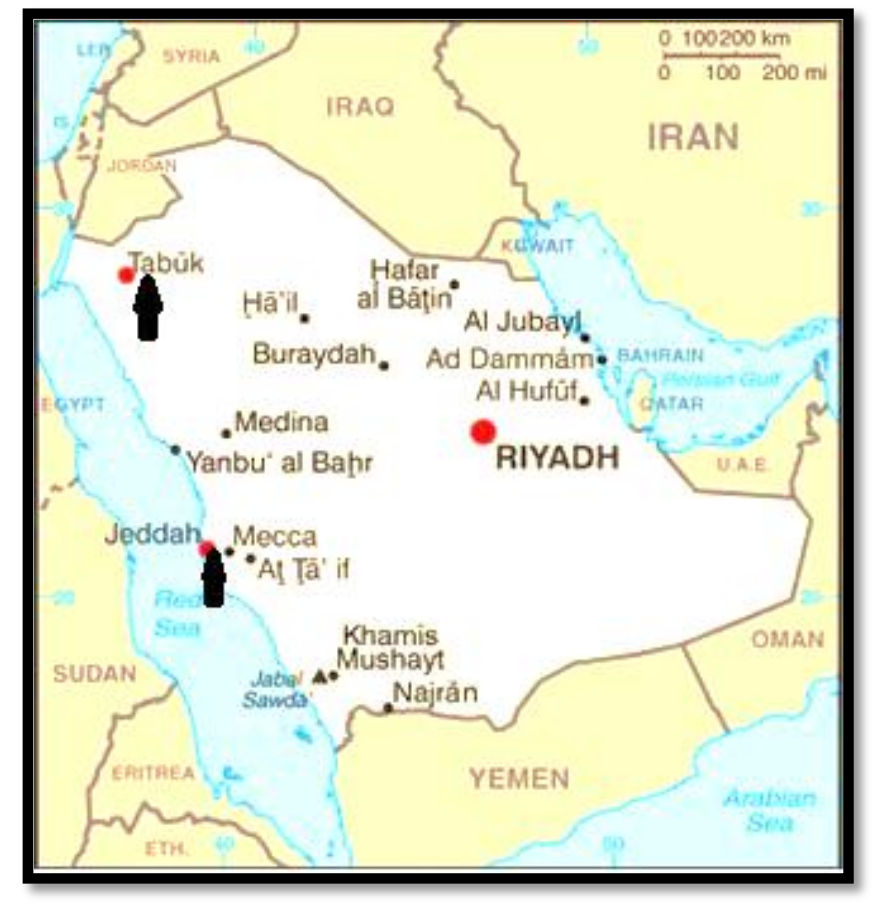

Fig. 1: Map of Saudi Arabia illustrating the geographical position of Tabuk and Jeddah ( $)$ districts.

These regions are known for of medicinal herbs of typical effective their variety of flora and fauna, and diverse natural habitats like sandy deserts, hills and mountains of unique rock formations. To collect 
information of the plant species, recipes, their local names, mode of administration and dosage, some herbalists, traditional healers and rural dwellers were consulted and interviewed with the aid of questionnaires designed precisely by the present researchers. A great number of these selected informants (different ages) had lived most of their lives in Tabuk and Jeddah. The interviews were carried out personally to document information and collect herbarium specimens of medicinal herbs used in typical effective impacts in treating scorpion stings. The information was mostly provided by individuals aging between 35 and 75 years old, of which $65 \%$ men and $25 \%$ women, while the remaining $10 \%$ were younger individuals aging between 20 and 35 years old. The plants were initially identified by their vernacular names through consultations with the locals. Scientific identification of the plant species and families was done by the author according to the Flora of Saudi Arabia (Migahid, 1996), Wild Flowers of Saudi Arabia (Collenette, 1999) and confirmed by Indigenous Knowledge (IK) system. The most important medicinal compounds were collected from different literatures (Aldoweriej et al., 2016, De Queiroz et al.,2014, Martins and Petropoulos, 2016 and Shim et al., 2014). Ethical approval for this study was obtained from the headmen of the areas under study.

\section{RESULTS}

The findings of this study showed that there are plants of medicinal importance that have shown antivenom properties against scorpion stings in both Tabuk and Jeddah districts of Saudi Arabia (Table 1). Plants identified in this study have been tested by the healers and accordingly are quite efficacious. A total of twelve plant species belonging to eleven different families were noted from this survey, in the two different regions (6 species in each region) of Saudi Arabia. The present study indicates that plant species used in treatment of scorpion stings in each district are completely different. Traditional healers used different methods for preparing drugs. This mainly depends on the specific properties of the plants and that of the desired extract. The methods of drug preparation, dosage and route of administration of medicinal plants obtained during this study are enumerated in Table 1. Decoctions, infusions, pulverization and grinding are the most frequently used methods of preparation. It is also notable that some plants were prepared using more than one method.

Table1. Medicinal plants used by the traditional healers in the treatment of scorpion stings in Jeddah and Tabuk districts, Saudi Arabia.

\begin{tabular}{|c|c|c|c|c|c|}
\hline Family & Botanical name & $\begin{array}{l}\text { Vernacular } \\
\text { name/Region }\end{array}$ & Life form & $\begin{array}{l}\text { Parts } \\
\text { used }\end{array}$ & Preparation \\
\hline \multirow[t]{2}{*}{ Alliaceae } & Allium cepa $\mathrm{L}$. & Basal/Tabuk & $\begin{array}{l}\text { Perennial } \\
\text { herb }\end{array}$ & Bulb & $\begin{array}{l}\text { Bulbs are carefully washed, and then fried } \\
\text { and hot bulbs are applied externally to the } \\
\text { sting point (Once only to release the } \\
\text { contaminated blood). } \\
\text { Medical treatment is immediately needed } \\
\text { after this procedure. }\end{array}$ \\
\hline & Allium sativum $\mathrm{L}$. & Thoum/Jeddah & $\begin{array}{l}\text { Perennial } \\
\text { herb }\end{array}$ & Bulbuls & $\begin{array}{l}\text { Bulbs are carefully crushed then mixed with } \\
\text { honey and applied externally to the sting } \\
\text { point. } \\
\text { This treatment must be immediately applied } \\
\text { after sting. }\end{array}$ \\
\hline Apocynaceae & $\begin{array}{l}\text { Calotropis procera } \\
\text { (Aiton) W.T.Aiton }\end{array}$ & Oshar/Tabuk & Shrub & Leaves & $\begin{array}{l}\text { Fresh leaves are crushed, and then applied } \\
\text { externally to the sting point. } \\
\text { Medical treatment is needed directly after } \\
\text { this procedure. }\end{array}$ \\
\hline Asteraceae & Arctiumlappa L. & Arqatyon/Jeddah & $\begin{array}{l}\text { Biennial } \\
\text { herb }\end{array}$ & Roots & $\begin{array}{l}\text { Macerating fresh roots in water, mixed with } \\
\text { honey, then applied externally to the sting } \\
\text { point. } \\
\text { This treatment must be immediate after } \\
\text { sting. }\end{array}$ \\
\hline Boraginaceae & $\begin{array}{l}\text { Heliotropium } \\
\text { bacciferum Forssk. }\end{array}$ & Remram/Tabuk & Shrub & $\begin{array}{l}\text { Shoot } \\
\text { system }\end{array}$ & $\begin{array}{l}\text { Decoction of leaves or the whole shoot } \\
\text { system is prepared in adequate amount of } \\
\text { boiling water. One glassful is taken orally } \\
\text { once. The remaining of the boiled decoction } \\
\text { is applied externally to the sting point. } \\
\text { Salt may be added in the decoction. }\end{array}$ \\
\hline Burseraceae & $\begin{array}{l}\text { Commiphora myrrha } \\
\text { (Nees)Engl. }\end{array}$ & Morrah/Jeddah & Tree & Gum & $\begin{array}{l}\text { Gum powder is mixed with salt or dates, } \\
\text { and then applied directly at the sting point. } \\
\text { Sugar may be added with salt. }\end{array}$ \\
\hline Cucurbitaceae & $\begin{array}{l}\text { Citrullus colocynthis } \\
\text { (L.)Schrad. }\end{array}$ & Handal/Tabuk & $\begin{array}{l}\text { Perennial } \\
\text { herb }\end{array}$ & Fruits & $\begin{array}{l}\text { Half the fresh fruit is applied } \\
\text { externally at the sting point for half to one } \\
\text { hour, until its color turns black. } \\
\text { Medical treatment is needed immediately } \\
\text { after this procedure. }\end{array}$ \\
\hline Fabaceae & $\begin{array}{l}\text { Astragalus spinosus } \\
\text { Vahl. }\end{array}$ & Shagratalaarab/Tabuk & Shrub & $\begin{array}{l}\text { Shoot } \\
\text { system }\end{array}$ & $\begin{array}{l}\text { Fresh or dried leaves are crushed and boiled } \\
\text { in milk or water. One glassful of the leaf } \\
\text { decoction is taken orally once. The } \\
\text { remainder of the boiled leaves are applied }\end{array}$ \\
\hline
\end{tabular}




\begin{tabular}{|c|c|c|c|c|c|}
\hline & & & & & $\begin{array}{l}\text { externally to the sting point. } \\
\text { Decoction of the fresh or dried shoot } \\
\text { system in milk or water is taken orally, one } \\
\text { glassful is taken once. } \\
\text { Infusion of crushed leaves or dried shoot } \\
\text { system is prepared by macerating it into } \\
\text { adequate amount of water and is used in the } \\
\text { same way as above. }\end{array}$ \\
\hline Linaceae & $\begin{array}{l}\text { Linum usitatissimum } \\
\text { L. }\end{array}$ & Kitan/Jeddah & $\begin{array}{l}\text { Perennial } \\
\text { herb }\end{array}$ & Seeds & $\begin{array}{l}\text { Seed powder is mixed in water, and then } \\
\text { applied directly to the sting point. } \\
\text { Salt may be added. } \\
\text { This treatment must be applied } \\
\text { immediately after sting. }\end{array}$ \\
\hline Pedaliaceae & Sesamum indicum L. & Semsem/Jeddah & $\begin{array}{l}\text { Annual } \\
\text { herb }\end{array}$ & Seeds & $\begin{array}{l}\text { Seed oil is applied directly to the sting point } \\
\text { every fifteen minutes. } \\
\text { This treatment must be continued for } \\
\text { twenty four hours. }\end{array}$ \\
\hline Rutaceae & $\begin{array}{l}\text { Citrus aurantifolia } \\
\text { (Christm.)Swingle }\end{array}$ & Lymon/Jeddah & Tree & Fruits & $\begin{array}{l}\text { Fruit juice is applied directly to the sting } \\
\text { point. } \\
\text { This treatment must be applied immediately } \\
\text { after sting. }\end{array}$ \\
\hline Solanaceae & $\begin{array}{l}\text { Datura stramonium } \\
\text { L. }\end{array}$ & Datura/Tabuk & Shrub & Leaves & $\begin{array}{l}\text { Leaves are dried, crushed, heated and } \\
\text { mixed with flour, then applied externally to } \\
\text { the sting point. } \\
\text { Medical treatment is immediately needed } \\
\text { after this procedure. }\end{array}$ \\
\hline
\end{tabular}

Analysis of the growth forms of the recorded medicinal plants (Figure 2) reveals that shrubs constituted the largest number or proportion being represented in Tabuk by four species $(67 \%)$ followed by two species of perennial herbs $(33 \%)$.However, in Jeddah both perennial herbs and trees represented the largest percentage (33\%) followed by biennial herbs and annual herbs (17\%).

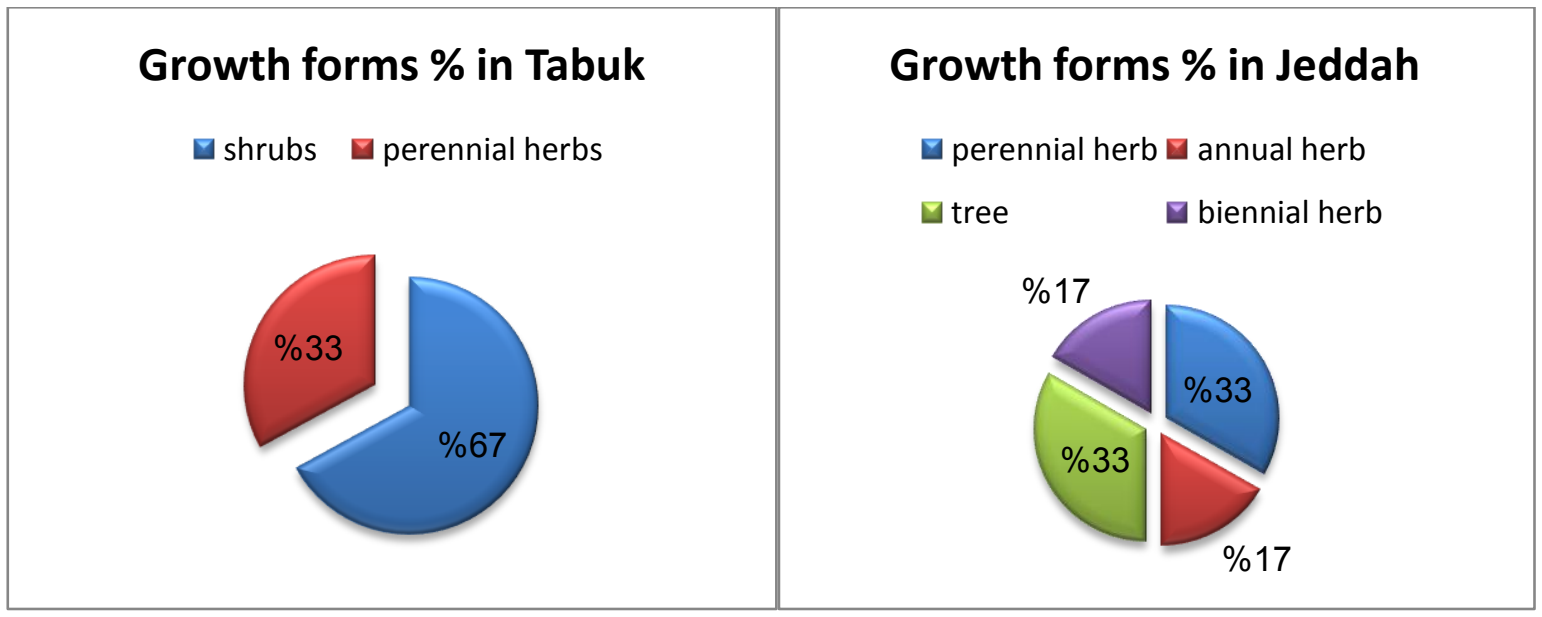

Fig. 2: Growth forms percentage reported of ethno medicinal plant species in the two districts- Tabuk and Jeddah in Saudi Arabia.

Different parts of the plants used in the treatment of scorpion stings in the study area is shown in Figure 3. The most frequently used plant parts in Tabuk are the leaves (66\%) followed by fruits (17\%) and bulbs (17\%) while in Jeddah seeds are the most frequently plant part used (33\%) followed by other parts almost in same percentages. 


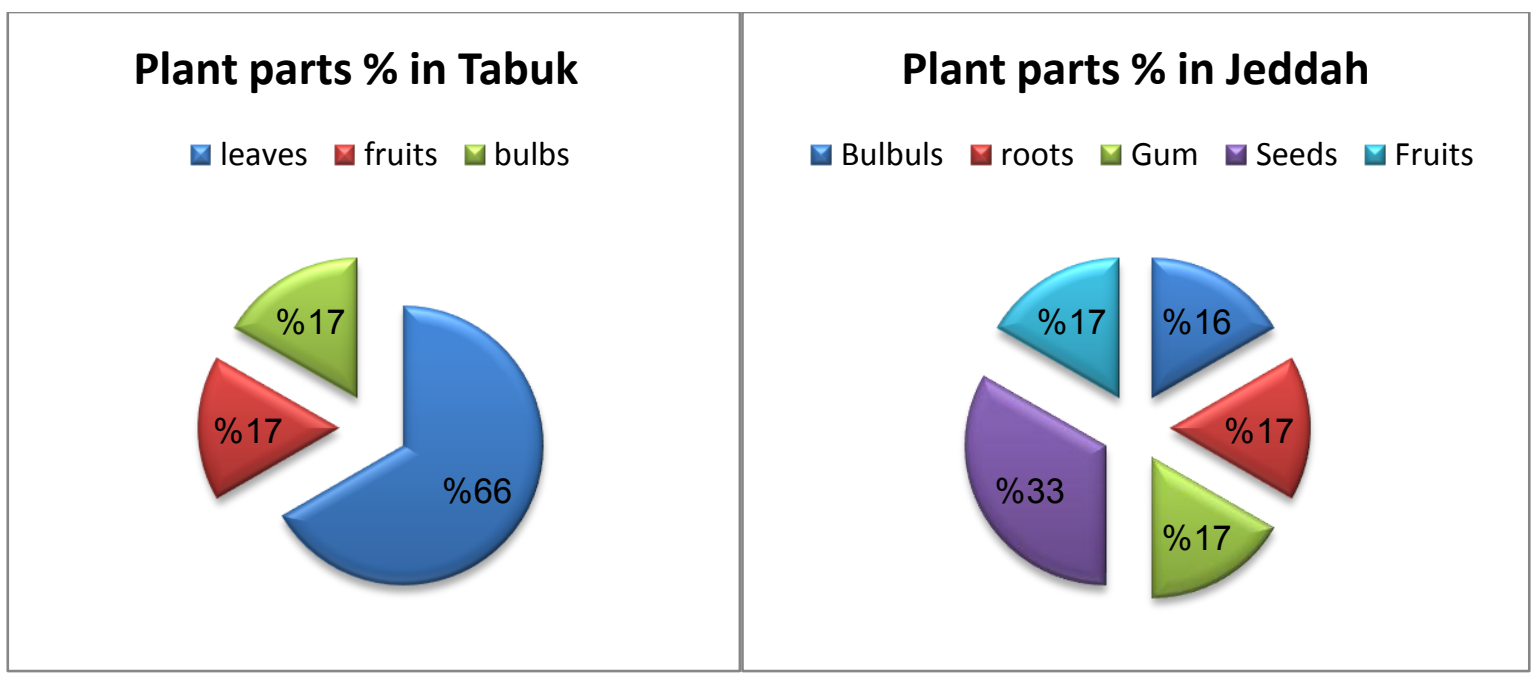

Fig. 3: Percentages of medicinal plant parts used by traditional healers for treatment in the two districts- Tabuk and Jeddah in Saudi Arabia.

Categories of the medicinal plants, based on the degree of usage as reported by informants, reveals that Astragalus spinosus (45\%) and Heliotropium bacciferum (27\%) are the most prominent species in the recipes and frequently used by traditional healers for remedy preparations in Tabuk. While in Jeddah Allium sativum (53\%) and Linum usitatissimum (20\%) are the most prominent used species (Figure 4).

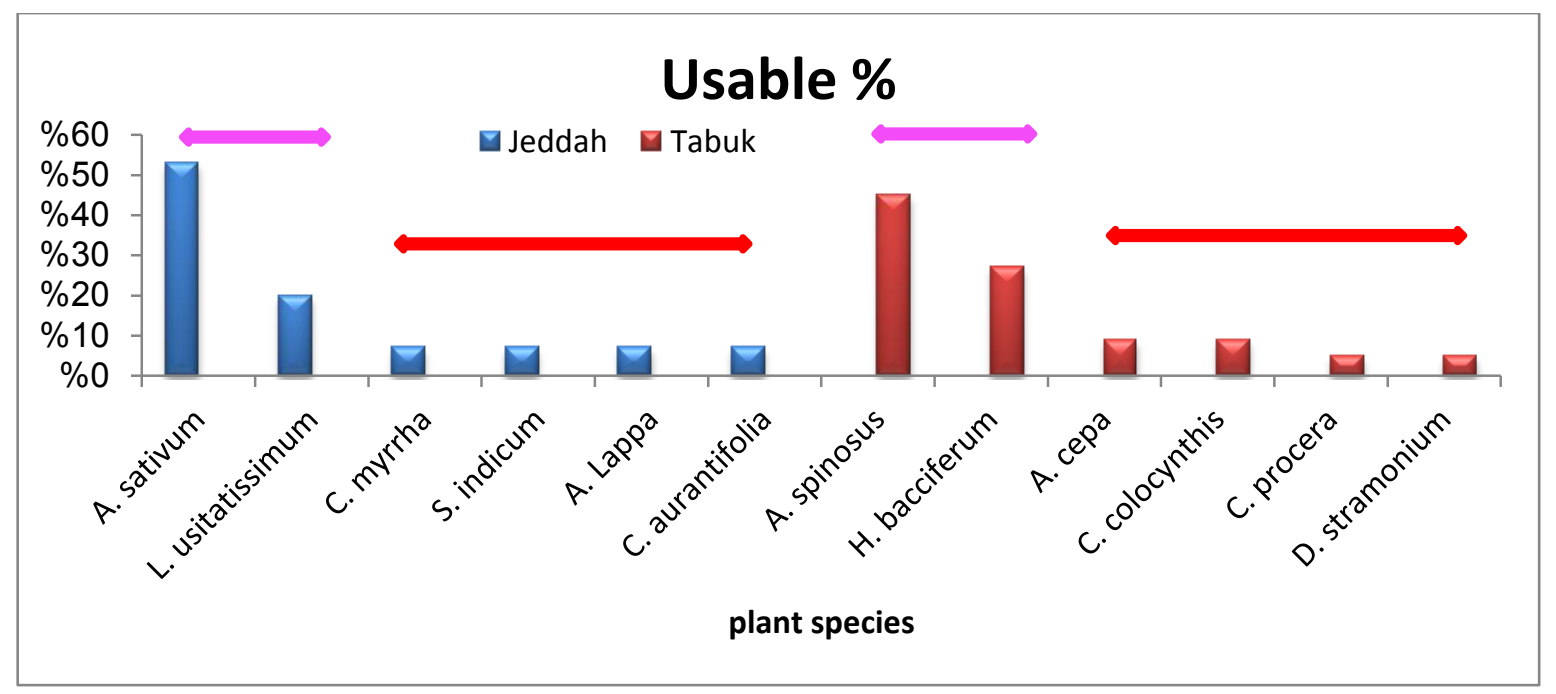

Fig. 4: Categories of medicinal plants used by traditional healers based on the degree of usage abundance (high $\longrightarrow$ and $\longleftrightarrow$ low ) in the two districts- Tabuk and Jeddah in Saudi Arabia.

The main phytochemical compounds, in the most commonly used plant species in the study area, were identified with references to their effectiveness in the treatment of scorpion stings. The collected data indicates that total phenolic compounds and flavonoids could represent the main effective group of secondary metabolites in the treatment of scorpion stings and in managing the effects of sting complications. Martins and Petropoulos (2016) and De Queiroz et al.,(2014) found that total phenolics, organosulfur compounds, flavonoids allicin and phytosterol were the main bioactive compounds in Allium sativum. While in Astragalus spinosus, flavonoids, saponin and total phenolics (Aldoweriej et al., 2016). In Heliotropium bacciferum, total phenolics \& flavonoids, pyrrolizidine alkaloids are important (Aldoweriej et al., 2016 and Alanazi et al., 2016). Shim et al., 2014 noted that other active compounds in Linum usitatissimum are represented byomega-3 fatty acids, lignans, cyclic peptides, polysaccharides, alkaloids and cyanogenic glycosides. Most biological and clinical studies of flax seed have focused on a-linolenic acid or lignans. 


\section{DISCUSSION}

Since ancient times, a poisonous animal bite is a serious issue in the world. Millions of people die every year because of poisonous animals. Scorpion sting is a common and global public health problem associated with substantial morbidity and mortality. It constitutes an occupational hazard for rural population. The factors mainly responsible for high mortality associated with scorpion sting are poor health services, difficult and untimely transportation facilities, wrong traditional beliefs, delay in anti-scorpion venom administration. Few investigations of the scorpion fauna has been made in Saudi Arabia. Fet et al.(2000) gave references to as many as 25 species and subspecies, and Hendrixson (2006) suggested that there are at least 17 nominal species within ten genera in Saudi Arabia. Chemically, scorpion venom is a cocktail of several neurotoxins, cardio toxins, nephron toxins, hemolytic toxins, nucleotides, amino acids, oligopeptides, phospholipase-A, hyaluroinidase, acetylcholine esterase, histamine, serotonin, 5-hydroxyptamine and proteins that inhibit protease, angiotensinase and succinate dehydrogenase (Bawaskar and Bawaskar, 2012). A clinical effect of the envenomation depends upon the scorpion species, lethality and dose of venom injected at the time of sting, and on the victim's physiological reactions to venom. Clinical features of the patients stung by scorpion are generally abnormalities indicative of major body systems like cardiac, respiratory, autonomic and metabolic changes. Most patients die of multisystem failure. The autonomic over-activity, pulmonary edema, acute myocarditis and ischemia-like changes are the most frequent manifestations. There is no standard protocol for the treatment of scorpion venom poisoning. The treatment strategies practiced for these patients include drug regimens like prazosin, angiotensin-converting enzyme (ACE) inhibitors, insulin, anti-scorpion venom serum (AScVs) and others (Murthy et al., 1991 and Bagchi and Deshpande, 1998).

A considerable number (6) of medicinal plants used by local communities in Tabuk and the other six species in Jeddah to treat scorpion stings have been documented throughout the study period. Ethno pharmacological literature offers a large amount of data relating to similar species (the represented genus) used to treat scorpion stings in other bio geographical regions [e.g., (Oluwatoyin et al., 2011) and (Mafimisebi et al., 2012)]. The collected information indicates the depth of the local indigenous knowledge of medicinal plants and their application in the study area. The majority of the recorded medicinal plants in Tabuk( 5 species, representing 83\%) are belonging to the wild flora and only one species (Allium cepa) is cultivated and edible. In contrast, the majority of the recorded species in Jeddah (4 species, representing 68\%) are belonging to the cultivated edible species. This difference may be due to the different culture or different types of scorpions in the two districts. The impact of scorpion sting varies in different regions and countries due to lifestyle, economic-social status, residential status, way of providing health services, and species present in each geographical area (Cheng, 2002). Some scorpion species endemic to the north of Saudi Arabia are the most toxic and highly venomous (Al-Asmar I et al., 2007, Al-Asmari et al., 2009). The present study reveals that medicinal plants play a vital role in the primary health care of the population in the study area. During this survey, it is observed that more than $80 \%$ of the total number of people questioned regularly used medicinal plants to treat many ailments, including scorpion stings. Most of the plant species reported in this study are also used for treatment of scorpion stings in other parts of the country and elsewhere. The fact that some of the reported plants have similar uses elsewhere can be taken as indication of their pharmacological effectiveness (Bahrkar et al., 2012 and Naturu et al., 2013). Salama and Sharshar (2013) found that total protein contents and SDS-PAGE analysis of different species collected from different localities in Egypt, showed differences between the protein compositions and concentrations of different scorpion's venom. They also reported that one of the factors that may influence venom toxicity and cause variable results is environmental conditions. The informants in the study area reported that A. spinosus attained the highest usable percentage followed by $H$. bacciferumin in Tabuk, while A. sativum followed by L. usitatissimum in Jeddah. These plant species have high amounts of flavonoids, total phenolic compounds, saponins, alkaloids, fatty acids and cyclic peptides (Aldoweriej et al., 2016). The folklore medicinal plants contain various types of flavonoids, steroids, terpenoids, alkaloids, tannins and coumarins that may account for their anti-venom potentials (Bin Asad et al., 2011 and Mansour et al., 2011). Farrag et al. (1996) and Alanazi et al.(2016) recorded that H. bacciferum is a herbal plant used in traditional medicine and reported to have cytotoxic effects due to pyrrolizidine alkaloids including Heliotrine, Heleurine, Supinine, Europine. Roy, (2015) recorded that Heliotropium species is hepatoxic and the internal use is not recommended. While in the present study in Tabuk district; decoction of leaves or the whole shoot system is prepared by boiling it in adequate amount of water. One glassful is taken only once. The remainder of the boiled plant parts is applied externally at the sting point. This may indicate that the effectiveness of this plant species is achieved at a certain dose. So, further studies are required to identify the phytochemicals responsible for anti-scorpion activity of these medicinal plants. In addition, pharmacological and clinical trials will help in the confirmation of the efficacy of the reported plant species. The anti-venom activity of a plant cannot be attributed to a single active ingredient; however, the overall activity results from the synergistic effect of various constituents on various target structures such as enzymes and receptors (Mansour et al., 2007 and Mansour et al., 2011). 


\section{CONCLUSION}

It can be concluded that the tribal people of Tabuk and Jeddah districts possess rich ethno pharmacological knowledge. They use several medicinal plant species in their traditional treatment for scorpion stings. These tribal people prefer keep this knowledge with them for their own profit. Despite the long history of treating scorpion stings in Saudi Arabia using herbal remedies, the knowledge and experience of these herbalists have not been scientifically documented. Data is always lost without any records after their passing away and lack of interest among the younger generation. Therefore, it is urgent need for identification and documentation. The present study provides a base for enhancing scientists' attention towards consideration of ethno medicinally important plants for scorpion stings 'treatment. The information available in this study could be helpful to scientists, drug designers, medicinal plant boards and other scientific bodies related to Ayurveda research in scorpion sting treatment. The herbs used in the treatment of scorpion stings in both Tabuk and Jeddah districts are easily available, common and cheap. The method of preparation and mode of action is also simple and convenient. Traditional medicinal knowledge is important not only for its potential contribution to drug development and market values but also for the healthcare professionals. A number of secondary metabolites viz.-alkaloids, phenolic compounds, flavonoids, terpenoids, glycolsides, fatty acids, and other metabolites are present in different plant parts. These compounds exhibit various pharmacological activities and are being used to treat scorpion stings and hence these plants may become a good source of indigenous medicines. Further studies of plant species mentioned in this study are required for chemical contents and toxicity, if any, that may help to increase the efficacy of their claims.

\section{ACKNOWLEDGEMENT}

The authors are highly thankful to traditional herbalists, traditional healers and rural dwellers for their cooperation and providing us with valuable information.

\section{REFERENCES}

Abu-Rabia, A., 2011. Urinary diseases and ethnobotany among pastoral nomads in the Middle East.Journal of Ethnobiology and Ethnomedicine. 1: 1-3.

Alanazi, A.K., B.A. Alahmadi, A. Alhimaidi, F.M. Abou-Tarboush, M. Abul Farah, A. Mahmoud and M. Alfaifi, 2016. Development of spermatic granuloma in albino rats following administration of water extract of Heliotropium bacciferum Forssk. Saudi Journal of Biological Sciences, 23: 87-91.

Al-Asmari, A.K., A.A. AL-Saif and N.M. Abdo, 2007. Morphological identification of scorpion species from Jazan and Al-Madina Al-Munawara regions, Saudi Arabia. J. Venom. Anim. Toxins incl. Trop. Dis., 13: 821-843.

Al-Asmari, A.K., A.A. AL-Saif, N.M. Abdo and K.R. Al-Moutaery, 2009. The scorpion fauna of Al-Baha and Hail regions, Saudi Arabia. J. Biological Sciences, 9: 96-108.

Al-Asmari, A.K., H.A. Khan, R.A.M anthiri, 2015. Effect of Androctonus bicolor scorpion venom on the activities of serum enzymes in rats. Int. J. Clin. Exp. Med., 8: 11734-11737.

Al-Asmari, A.K., R.A. Manthiri, N. Abdo, F.A. Al-Duaiji and H.A. Khan, 2016. Saudi medicinal plants for the treatment of scorpion sting envenomation. Saudi Journal of Biological Sciences, in press.

Aldoweriej, A.M., K.B. Alharbi, E.M.A. Saeed and I.M. El-Ashmawy, 2016. Anti-microbial activity of various extracts from some plants native to Alqassim Region, Saudi Arabia Journal of Food, Agriculture \& Environment., 14: 14-19.

Bafeel, S.O., A. Alaklabi, I.A. Arif, H.A. Khan, A.H. Al Farhan, A. Ahamed, J. Thomas, M.A. Bakir, 2012b. Ribulose-1, 5-biphosphate carboxylase (rbcL) gene sequence and random amplification of polymorphic DNA (RAPD) profile of regionally endangered tree species Coptospermagraveolens subsp. Arabicum (S. Moore) Degreef. Plant Omics, 5: 285-290.

Bafeel, S.O., I.A. Arif, M.A. Bakir, A.A. Al Homaidan, A.H. Al Farhan, H.A. Khan, 2012a. DNA barcoding of arid wild plants using rbcL gene sequences. Genet. Mol. Res., 11: 1934-1941.

Bafeel, S.O., I.A. Arif, M.A. Bakir, H.A. Khan, A.H. Al Farhan, A.A. Al Homaidan, A. Ahamed, J. Thomas, 2011. Comparative evaluation of PCR success with universal primers of maturase K (matK) and ribulose-1,5-bisphosphate carboxylase oxygenase large subunit (rbcL) for barcoding of some arid plants. Plant Omics, 4: 195-198.

Bagchi, S. and S.B. Deshpande, 1998. Indian red scorpion (Buthustamulus) venom-induced augmentation of cardiac reflexes is mediated through the mechanisms involving kinins in urethane anesthetized rats. Toxicon., 36: 309-20. 
Bahrkar, S., R. Kale and Sh. Nagpure, 2012. A review on medicinal plants used in scorpion bite treatment in India. Mintage Journal of Pharmaceutical\& Medical Sciences, 1: 1-6.

Bawaskar, H.S. and P.H. Bawaskar, 2012. Scorpion Sting: Update.JAPI January, 60: 46-55.

Bin Asad, M.H.H., G. Murtaza, S. Siraj, S.A. Khan, S. Azhar, M.S. Hussain, T. Ismail, M.S. Hussain, I. Hussain, 2011. Enlisting the scientifically unnoticed medicinal plants of Pakistan as a source of novel therapeutic agents showing anti-venom activity.African J. Pharm. Pharmacol., 5: 2292-2305.

Cheng, D., 2002. Scorpion sting. E-medicine J. 3: 1-29.

Collenette, S., 1999. Wildflowers of Saudi Arabia National Commission for Wild life Conservation and development (NCWCD) KSA.

De Queiroz, Y.S., P.B. Antunes, J.V. Silvio, S.J.V. Vicente, G.R. Sampaio, J. Shibao, D.H.M. Bastos and E.A.F.da S. Torres, 2014. Bioactive compounds, in vitro antioxidant capacity and Maillard reaction products of raw, boiled and fried garlic (Allium sativum L.). International Journal of Food Science and Technology, 49: 1308-1314.

Devarbhavi, P.K. and V. Murthy, 2013. Scorpion sting envenomation - An Overview.J Clin Biomed Sci., 3(4): 159-66.

Farrag, N.M., A.M. Abdel - Aziz, M. El-Shafae, A.M. Aleya, M.M. El-Domiaty, 1996. Pyrrolizidine alkaloids of Heliotropium bacciferum Forssk.from Egypt, 34(5): 374-377.

Fet, V., W.D. Sissom, G. Lowe and M.E. Braunwalder, 2000. Catalogue of the scorpions of the world (1758-1998). New York, New York Entomological Society.

Fransworth, N.R. and D.D. Soejarto, 1985. Potentil consequences of plant extinction in the United States on the current and future availability of prescription drugs.Economic Botany, 39: 231-240.

Ghazanfar, S.A., 1994. Handbook of Arabian Medicinal Plants. CRC Press, Boca Raton, FL, pp: 265.

Hendrixson, B.E., 2006. Buthid scorpions of Saudi Arabia, with notes on other families (Scorpions: Buthidae, Liochelidae, Scorpionidae). Fauna of Arabia, 21: 33-120.

Karnad, D.R., 2009. Management of scorpion envenomation: need for a standard treat ment protocol using drugs and antivenom. J. Assoc. Phys. India, 57: 299-300.

Mafimisebi, T.E., A.E. Oguntade, A.N. Fajemisin and O.P. Aiyelari, 2012. Local knowl- edge and socioeconomic determinants of traditional medicines' utilization in livestock health management in Southwest Nigeria. Journal of Ethnobiology and Ethnomedicine, 8: 2.

Mansour, N.M., M.N. Tawfik, T.R. Rahmy and A.E. Yaseen, 2007. Prophylactic effect of Ambrosia maritima plant extract on renal tissues of rats envenomed with Leiurusquinquestriatus scorpion. Egypt. J. Nat. Toxicol., 4: 101-130.

Mansour, N.M., M.N. Tawfik, A.E. Yaseen and T.R. Rahmy, 2011. Protective role of ambrosia maritime Plant extract against alterations induced by leiurus quinquestriatus Scorpion venom on skeletal muscles and Intestinal tissues of rats. Egypt. J. Nat. Toxicol., $8: 81-103$.

Martins, N. and S. Petropoulos, 2016. Chemical composition and bioactive compounds of garlic (Allium sativum L.) as affected by pre- and post-harvest conditions: A review. Food Chemistry, 211: 41-50.

Migahid, A.M., 1996. Flora of Saudi Arabia vol. 1, 2, 3.King Saud University, Riyadh, KSA.

Murthy, K.R., R. Shenoy, P. Vaidyanathan, K. Kelkar, N. Sharma, N. Birevar, 1991. Insulin reverses haemodynamic changes and pulmonary edema in children stung by the Indian red scorpion Mesobuthustamulusconcanesis, Pocock. Ann Trop Med Parasitol., 85: 651-7.

Naturu, S., Y. Pulicherla, L. Mattigunta and V. Ramana, 2013. Traditional phytotherapy treatment for snake bite and scorpion sting by ethnic groups of Kadapa district, Andhra Pradesh, India. Int. J. Pharm. Sci. Rev. Res., 20: 64-70.

Oluwatoyin, M.S., G.N.I lleogbulam, A. Joseph, 2011. Phytochemical and antimicrobial studies on the aerial parts of Heliotropium indicum Linn. Annals of Biological Research, 2: 129-136.

Roy, A., 2015. Pharmacological Activities of Indian Heliotrope (Heliotropium indicum L.): A Review. Journal of Pharmacognosy and Phytochemistry, 4: 101-104.

Salama, W.M. and K.M.S harshar, 2013. Surveillance study on scorpion species in Egypt and comparison of their crude venom protein profiles. The Journal of Basic \& Applied Zoology, 66: 76-86.

Shim, Y.Y., B. Guia, P.G. Arnisonb, Y. Wang, and M.J.T. Reaney, 2014. Flaxseed (Linum usitatissimum L.) bioactive compounds and peptide nomenclature: A review* Trends in Food Science \& Technology, 38: 520.

Shinwari, Z.K., 2010. Medicinal plants research in Pakistan. J. Med. Plants Res., 4: 161-176.

Yogamaya, D., K.S. Rajani and D. Bandita, 2011. Ethnomedicinal survey of Koraput district, Odisha: An Update.Journal of Pharmacy Research, 4: 4142-4145. 